M. Fredj ${ }^{1,2}$, Dr. Sc. (Tech.), orcid.org/0000-0002-0560-4941, A. Hafsaoui ${ }^{1}$, Dr. Sc. (Tech.), Prof., orcid.org/0000-0002-1720-9527, H. Riheb ${ }^{3}$, Dr. Sc. (Tech.), Prof., orcid.org/0000-0002-9632-0812, R. Boukarm², Dr. Sc. (Tech.), orcid.org/0000-0002-9387-5812, A. Saadoun ${ }^{1,2}$, Dr. Sc. (Tech.), orcid.org/0000-0001-7860-6107
1 - Natural Ressources and Planning Laboratory, Badji Mokhtar University, Annaba, Algeria, e-mail: mohamed. fredj@univ-bejaia.dz; abderrazak.saadoun@univ-bejaia.dz 2 - Mining and Geology Department, Abderrahmane Mira University, Bejaia, Algeria, e-mail: riadh.boukarm@univ-bejaia.dz 3 - Department of Earth Sciences, Sétif-1 University, Sétif, Algeria, e-mail: hadji.rihab@univ-setif.dz

\title{
BACK-ANALYSIS STUDY ON SLOPE INSTABILITY IN AN OPEN PIT MINE (ALGERIA)
}

Purpose. To analyze the sliding from the geotechnical point of view and to identify the plausible causes that influence it.

Methodology. To analyze the sliding from the geotechnical point of view and to identify the plausible causes that influence it, our study follows the following chronological order. Firstly, a feedback reconstructs the slip from the geotechnical point of view; a back-analysis is required to confirm the surface failure. Next, a check will be made of the surface failure through the finite difference method and using the shear strength reduction by finite difference method (SSR-FD). A parametric study on the influence of the geometric parameters is performed to see the influence of the latter on the stability. The plausible cause that has directly influenced this sliding is shown.

Findings. This paper considers the application of three methods: limit equilibrium method (LEM), finite element method (FEM) and finite difference method (FDM) to perform back analysis and find out the layer of slope failure in an open pit mine.

Originality. Three different approaches LEM, FEM and FDM were used to perform the back-analysis the rock mass properties and to investigate the slope failure mechanism and the accuracy of this method in mining engineering field.

Practical value. This study has illustrated that non-compliance with the art, open pit mining standards and early planning of the mining method can most often lead to critical situations and catastrophic results. The back analysis of the slip site allowed us to reconstruct the break already observed and to draw maximum lessons on the mode, location and mechanical parameters that triggered this break.

Keywords: landslide, limit equilibrium method, finite difference method, finite element method, open pit mine, slope stability

Introduction. Study and analysis of slope stability are routinely performed in quarries and open pit mines. They are found at the planning and slope design stages to ensure the long-term stability of the mine, on the one hand, and, on the other hand, to minimize the volume of waste rock to be excavated [1].

The stability analyses of slopes (mines and quarries) require an understanding of the geology, hydrogeology, seismology and geotechnics of the site in addition to knowledge of analytical and numerical methods [2, 3]. In order to properly use an analysis method, the degree of investigation done on the site and the amount of data retrieved must be similar to the complexity of the analysis method used $[4,5]$. These analyses are also carried out at the production stage when the slopes show signs of instability or breakage [6]. At this stage, it is common to perform analysis on events that have already occurred. This is called a back-analysis of the slopes instability.

The back-analysis is a technique that allows reconstructing the failure already observed to draw maximum information on the mode, location and mechanical parameters that have triggered this failure. The geometry of the failure surface represents a primordial and essential step to characterize a natural or anthropogenic landslide [7-9]. In the area of slopes and embankments, Sakurai work (2017) [10] is a reference in the field. The back-analysis involves sensitivity analysis using the limit equilibrium method by 2D slope stability software. Sensitivity analysis is used to determine the material property with the most significant influence on the stability of the slope.

The concept of the back-analysis is to assume that a safety factor equal to 1.0 characterizes the slope in the moment of critical failure and to determine the parameters of the sliding layer at the moment of this critical state.

(C) Fredj M., Hafsaoui A., Riheb H., Boukarm R., Saadoun A., 2020
On September 8, 2007 at 5:00 a.m., a spectacular event occurred in the phosphate open pit mine. It is a major landslide, which had completely filled the pit. For this reason, the main objective of this paper is to analyze the sliding from the geotechnical point of view and to identify the plausible causes that influenced it.

Analysis Methods. Limit Equilibrium Methods. Limit equilibrium methods (LEMs) are mostly used for slope stability studies. In this work, the software SLIDE 2D limit equilibrium analysis of slope stability by Rocscience is applied to perform back analysis and find out the material property of the layer generating the movement.

Numerical Methods. With an important progress in computer technology along with low cost, the application of numerical methods (NMs) in slope stability analysis has become progressively common. The NMs are a powerful tool for solving many engineering problems. The FEM and FDM are two of these methods. In our work, this analysis is performed through the software Phase 2 finite element analysis for excavation by Rocscience Inc., and FLAC (Fast Lagrangian Analysis of Continua) by Itasca. In the FEM and FDM, the factors of safety were obtained by technique of the Shear Strength Reduction (SSR). One main advantages of the SSR technique over LEM slope stability analysis is the critical slide surface is found automatically, and it is not necessary to specify the shape of the slide surface in advance. In this SSR technique, slope stability is defined using rock strength characteristics as follows

$$
\begin{gathered}
C^{*}=\frac{1}{F^{*}} C ; \\
\varphi^{*}=\arctan \left(\frac{1}{F^{*}} \tan \varphi\right),
\end{gathered}
$$

where $C^{*}$ and $\varphi^{*}$ are rock reduced strength characteristic, (cohesion and friction angle) in proportion to the real values $(C, \varphi)$. 
Methods. To analyze the sliding occurring in the phosphate open pit mine from the geotechnical point of view and to identify the plausible causes that influenced it, our study follows the following chronological order. Firstly, a feedback reconstructs the slip from the geotechnical point of view; a backanalysis is required to confirm the nature of the slip and the location of the surface failure. Next, a check is made of the surface failure through the finite difference method and using the shear strength reduction by difference finite method (SSRFD). In addition, a parametric study on the influence of the geometric parameters (bench height and dip angle) is performed to see the influence of the latter on the stability. Finally, we show the plausible cause that has directly influenced this sliding, namely the method of exploitation.

Project Background. Kef Essnoun mine is located on the southern flank of Jebel El-Onk (Northeast of Algeria), about $10 \mathrm{~km}$ Southwest of Bir El-Ater city. This deposit, which was commissioned in 2001, was the heart of the mine in the years preceding the landslide, with annual production exceeding 3.5 million tons for national and international markets.

On September 8, 2007 at 5:00 a.m., a spectacular event occurred in the phosphate open pit mine. It was a major landslide, which had completely filled the pit (Fig. 1,b). Following the landslide movement, the slipped mass covered an area of almost 11 ha with an average thickness of about $75 \mathrm{~m} \mathrm{(30} \mathrm{m} \mathrm{of}$ phosphate and $45 \mathrm{~m}$ of overlying terrain); the volume of the slipped mass was estimated at 7.7 million $\mathrm{m}^{3}$ [11].

Before sliding occurred, the pit was cut at $70 \mathrm{~m}$ depth and had an overall face angle of $70^{\circ}$ (Fig. 1, a), made up of two benches of waste rock, the first of which extended over a length of $1778 \mathrm{~m}$ with a height of $15 \mathrm{~m}(H=15 \mathrm{~m})$. The second had a length of $2130 \mathrm{~m}$ and a height of $30 \mathrm{~m}(H=30 \mathrm{~m})$. For the phosphate-producing layer the height of the bench was of the order of $30 \mathrm{~m}(H=30 \mathrm{~m})$ with a length of $1536 \mathrm{~m}$. All the benches had a slope of $80^{\circ}\left(\alpha=80^{\circ}\right)$ [12].

Observation of the landslide area and Geotechnical model. Based on the direct observations carried out on the landslide, the North-South geological section of the landslide (Fig. 1, $b$ ) and its structure, the documentation communicated and the research work that has been done, the characteristics of the failure surface can be described as follows:

1. The terrain affected by the movement consists mainly of the exploited phosphate layer surmounted by overlays of marly limestone.

2. The existence at the base of the phosphate layer of a Pelitic and clay formation of the lower Thanetian represents a weak resistance compared to the phosphate layer.

From the above, it follows that the sliding surface is located at the level of the marl layer and that its shape follows the topography thereof.

Fig. 2 represents the limit equilibrium model that integrates the topographic and geological data used to carry out the back analysis of sliding of the north flank of the Kef-Essnoun Mine.

The main geotechnical parameters of the rocks for the four layers constituting the geological formation of the Kef-Essnoun deposit are presented in Table 1 .

Reflection on the possible causes of the sliding. To understand and analyze the sliding mechanism, one must take into account several influencing factors such as: hydrological and hydrogeological conditions, geometric parameters (slope height and dip angle) and dynamic effects (blasting effects)

Hydrological and hydrogeological parameters play a major role in the analysis of stability. Since the Jebel El-Onk area is considered an arid area. So the effect of these parameters had no direct relation to the triggering of the movement.

In the Kef-Essnoun mine, vibrations can come from two main sources. The first being the vibrations caused by earthquakes and the second being those caused by blasting. These vibrations are an important destabilizing element to take into account in stability analyses.
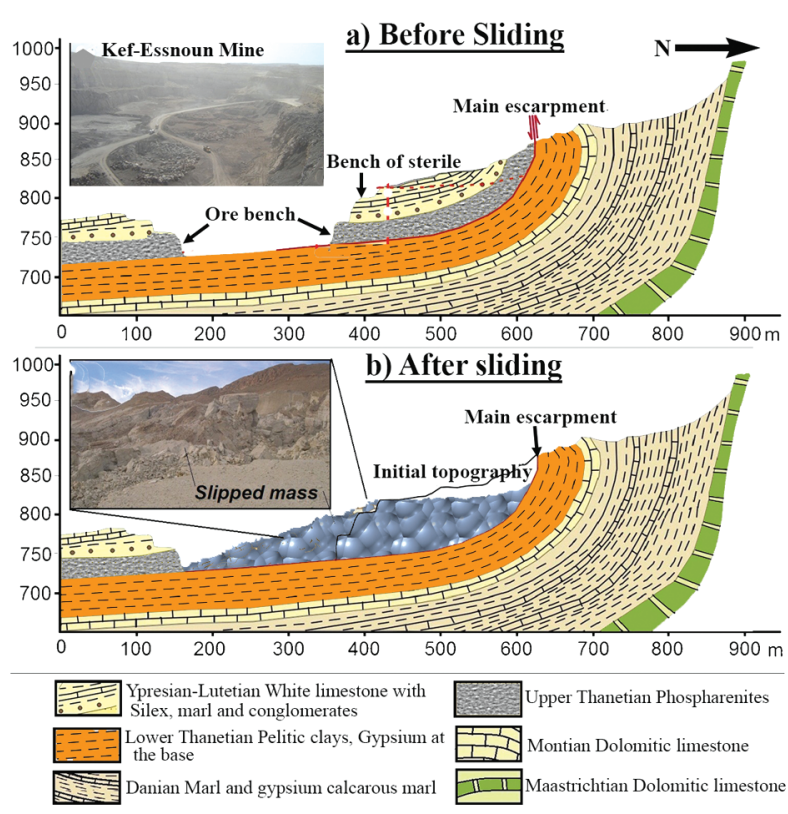

Fig. 1. Geological section of the Kef Essnoun mine: $a$ - before sliding; $b$ - after sliding

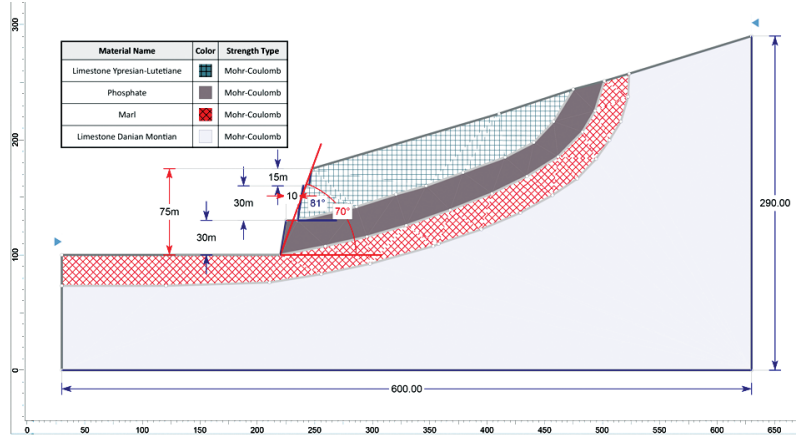

Fig. 2. Limit equilibrium model used in the back analysis

Vibrations caused by an earthquake are rare, but can affect the entire slope at the same time. According to the Algerian seismic regulation RPA99/Version 2003, the Tebessa province is located in seismic zone 1 in the seismic zoning map of the national territory; therefore, the seismicity effect was weak and had no relation to the landslide.

Explosive blasting is widely used in the Kef-Essnoun mine. The vibrations created by the blasting of explosives have two fields of action on the rock massifs. On the one hand, they affect the integrity of the rocks or their parameters of resistance to compression and, on the other hand, can cause a sliding of

Table 1

Geotechnical parameters of soils

\begin{tabular}{|c|c|c|c|c|c|c|}
\hline \multirow{2}{*}{ Materials } & UCS & $\gamma_{d}$ & $E$ & $C$ & $\varphi$ & $\psi$ \\
\cline { 2 - 7 } & $(\mathrm{MPa})$ & $\left(\mathrm{kN} / \mathrm{m}^{3}\right)$ & $(\mathrm{kPa})$ & $(\mathrm{kPa})$ & $\left({ }^{\circ}\right)$ & $\left({ }^{\circ}\right)$ \\
\hline 1 & 58.84 & 27 & 27000 & 5400 & 37 & 7 \\
\hline 2 & 49 & 21 & 24000 & 2300 & 35 & 5 \\
\hline 3 & 9.58 & 23 & 1000 & $C^{*}$ & $\varphi^{*}$ & 0 \\
\hline 4 & 19.17 & 27 & 27000 & 3600 & 37 & 7 \\
\hline$C^{*}$ and $\varphi^{*}:$ Unknown values (to be determined). \\
\hline
\end{tabular}

UCS: Unit compressive strength, $\gamma_{d}$ : dry unit weight, $v$ : Poisson's ratio, $E$ : Young's modulus, $C$ : cohesion, $\varphi$ : Internal friction angle, $\psi$ : dilatancy 
the slope when destabilizing actions are introduced. These vibrations are the result of the propagation of the shock wave in the rock mass. In this context, production shots fired repeatedly can contribute to worsening the stability of the mine.

To check the influence of geometric parameters and felling work on the sliding of our site a parametric study will be carried out.

Results and Discussions. LEM Back Analysis. In this study, the LEM and FDM methods were used to perform the backanalysis of the rock mass properties and to investigate the slope failure mechanism. Firstly, the shear strength parameters of the marl layer were back-calculated using the 2D limit equilibrium analysis of slope stability and sensitivity analysis were conducted. Then, incorporating the back analyzed parameters of the marl layer; the slope failure mechanism was numerically studied through FDM modelling.

Sensitivity analysis. Sensitivity analysis helps researchers evaluate the impact of an individual unknown variable, assuming all other parameters of the slope are known. In this analysis, one parameter varies and the other input parameters are kept constant. A sensitivity analysis indicates which input parameter may be essential to the assessment of slope stability and which of these parameters has a lesser effect on instability.

During the sensitivity analysis, the cohesion and the friction angle of the marl layer were analyzed. The results are presented as sensitivity graphs in Fig. 3 .

According to the analysis of the graphs (Fig. 3) showing the variation of the SF as a function of the cohesion and the internal friction angle of the marl layer, it is noted that for a safety factor of 1 , the values of cohesion $\left(C^{*}\right)$ and angle of friction $\left(\varphi^{*}\right)$ were $120 \mathrm{kPa}$ and $16.47^{\circ}$, respectively.

FDM Analysis. In this section, the SSR-FD method was used to provide a better understanding of the shape and location of the surface failure. The slope was modelled by FLAC2D software, which uses a two-dimensional explicit solution, allowing simulation of large deformations and instabilities. The geotechnical parameters of the marl layer, i.e. cohesion and friction angle, which were obtained from the LEM back analysis, were assigned to the model and the other geomechanical parameters of the north flank of kef Essnoun mine used in the SSR-FD modelling are given in Table 1 . The calculated safety factor was equal to $0.87(S F=0.87)$.

Fig. 4 shows that the surface failure is also situated along with the marl layer, which allows us to draw a certain conclusion: SSR-FD confirms slope instability and only possible sliding surface is along with the layer of marl.

LEM Parametric Study. In this section, the objective is to verify that they would have been the conditions of stability during the excavation work at the place where the landslide has developed, had the height and the angle of embankment being previously decreased. LEM analyses are performed, in order to calculate the safety factor (SF) by three methods (Bishop simplified, Spencer and GLE/M-Price's) for different angles and bench heights, along their critical failure surface. These analyses will be done in 3 possible cases. The first case consists in reducing the angle of inclination to 75 degrees $\left(\alpha=75^{\circ}\right)$ to obtain an edge angle of 63 degrees without modifying the bench height $(H=30 \mathrm{~m})$. The second is to reduce the bench height to 15 meters $(H=15 \mathrm{~m})$ with a tilt angle of 80 degrees $\left(\alpha=80^{\circ}\right)$. Finally, we reduce the angle of the slope to 75 degrees $\left(\alpha=75^{\circ}\right)$ while leaving the bench height of $15 \mathrm{~m}(H=15 \mathrm{~m})$. These analyses are all done both in static and dynamic load. Measurements on the ground of speed and seismic waves are frequently made with a seismograph. In our case, the values of horizontal and vertical accelerations are 0.05 and $0.0125 \mathrm{~m} / \mathrm{s}^{2} \mathrm{re}-$ spectively. The calculation results obtained are summarized in Table 2.

After analysis (Table 2) (Fig. 5), all the safety factors given by the different methods are higher than the minimum threshold allowed for slope stability $(S F>1)$, which allows us to draw certain conclusions.
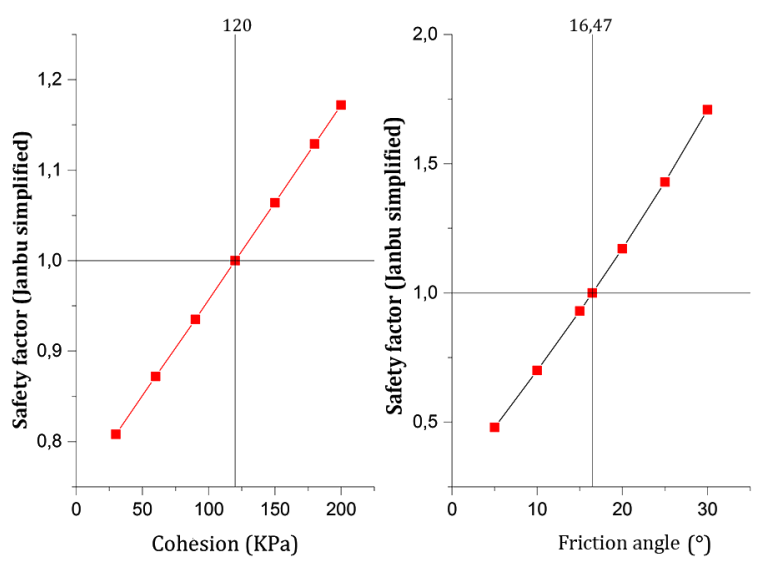

Fig. 3. Cohesion and friction angle for $S F=1$

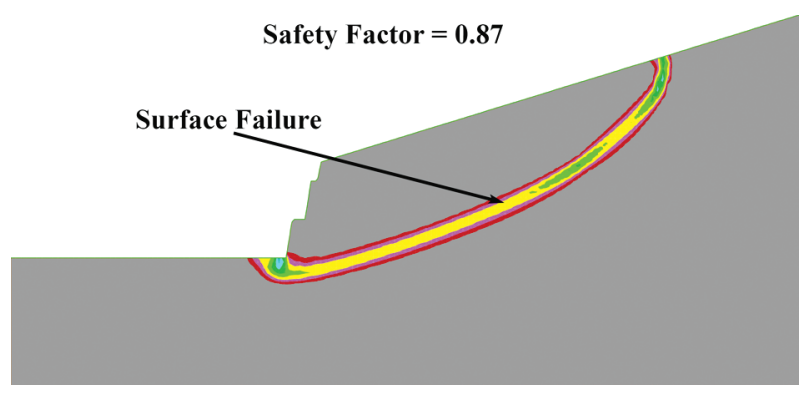

Fig. 4. Surface failure and SF value from FLAC

In the first case, all the safety factors given by the different methods in both cases (static and dynamic loads) are lower than the accepted minimum threshold for slope stability $(S F<1)$, which implies that the flank North of Kef-Essnoun is unstable, with a minimum safety factor, given by the Bishop simplified method $\left(S F_{\text {static }}=0.938\right.$ and $\left.S F_{\text {dynamic }}=0.825\right)$.

In the other cases, for the first approach where we did not take into account the seismicity coefficient (static load), all the safety factors are in critical condition $(S F=1)$, which confirms the influence of the angle and bench height on the flank stability of the mine with a minimum safety factor given by the Bishop simplified method $S F=1.063$ and $S F=1.073$.

Under dynamic load conditions, all the security factors given by the different methods are less than or equal to 1 $(S F \leq 1)$, with a minimum security factor, given by the Bishop simplified method $S F=0.932$ and $S F=0.940$.

In light of all these results, it can be concluded that the parameters studied did not have a direct influence on the slide of 2007. This leads us to make reservations about the choice of the operating method: from bottom to the top. Our study will focus on simulating a sinking operation method (from top to

Table 2

Summary of Safety Factors (SF) Calculation Results

\begin{tabular}{|c|c|c|c|c|}
\hline \multirow[b]{2}{*}{ Parameters } & \multirow[b]{2}{*}{ Cases } & \multicolumn{3}{|c|}{ Methods } \\
\hline & & $\begin{array}{c}\text { Bishop } \\
\text { simplified }\end{array}$ & Spencer & $\begin{array}{l}\text { GLE/ } \\
\text { Morgenstern- } \\
\text { Price }\end{array}$ \\
\hline \multirow{2}{*}{$\begin{array}{l}H=30 \mathrm{~m}, \\
\alpha=75^{\circ}\end{array}$} & Static load & 0.938 & 0.984 & 0.962 \\
\hline & Dynamic load & 0.825 & 0.886 & 0.852 \\
\hline \multirow{2}{*}{$\begin{array}{l}H=15 \mathrm{~m} \\
\alpha=80^{\circ}\end{array}$} & Static load & 1.063 & 1.124 & 1.100 \\
\hline & Dynamic load & 0.932 & 0.996 & 0.970 \\
\hline \multirow{2}{*}{$\begin{array}{l}H=15 \mathrm{~m} \\
\alpha=75^{\circ}\end{array}$} & Static load & 1.074 & 1.135 & 1.112 \\
\hline & Dynamic load & 0.940 & 1.006 & 0.980 \\
\hline
\end{tabular}




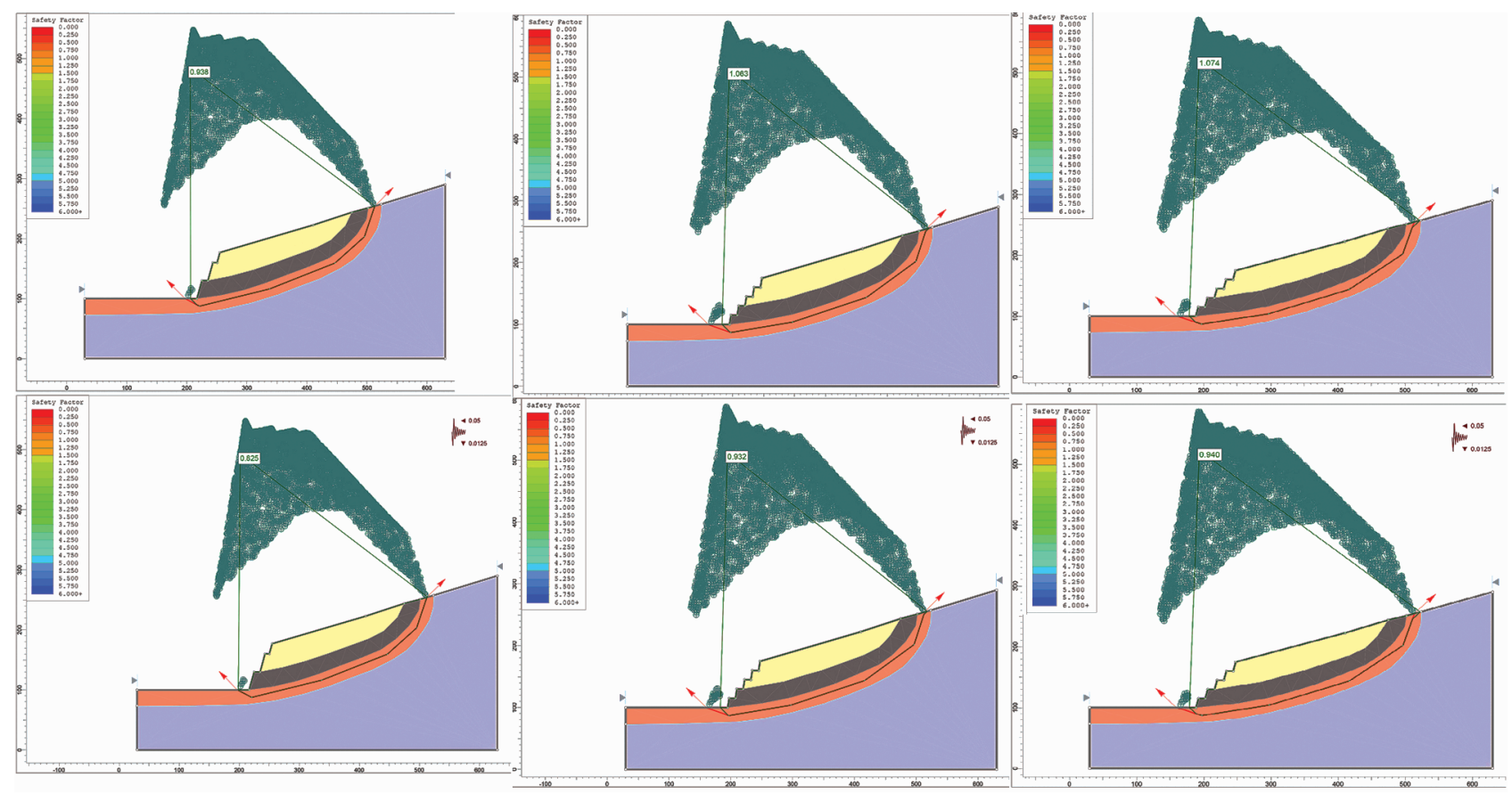

Fig. 5. Safety Factors under static and dynamic load from SLIDE

bottom) and analyzing the state of the slope under the same conditions that led to the slip.

Simulation of the operating method. In this part, we will simulate the exploitation method while analyzing the effect of the exploitation (digging of cutting trenches) on the north flank stability of the Kef-Essnoun mine. The calculation was done in phases (excavation sequence) taking into account the phase before operation. These different sequences are illustrated in Fig. 6.

Work Phasing. We will proceed by a calculation in phases (Fig. 7). The first phase consists of studying the stability of the north flank of the mine before any excavation is excavated. The second phase consists of opening of the mine and the beginning of the exploitation works. The following phases are the excavation phases as planned, according to the long-term planning, at regular intervals, leading to the last phase which represents the end-of-life flank.

The stability analysis will be done using the finite element method through Phase $^{2}$ finite element analysis for excavations software Rocscience Inc. The calculations will be in static and dynamic loads.

Stability analysis under Static load. The results of the calculation are summarized in Table 3 and maximum shear stresses and safety factors (in static condition) for different excavation phases are shown in Fig. 7.

According to the results of the numerical modelling, obtained by the shear strength reduction by finite element method (SSR-FE) under static load (Fig. 7) (Table 3), we find that: before exploitation (Phase 1) (Fig. 7), the safety factor given by SSR-FE is greater than the minimum admitted threshold for

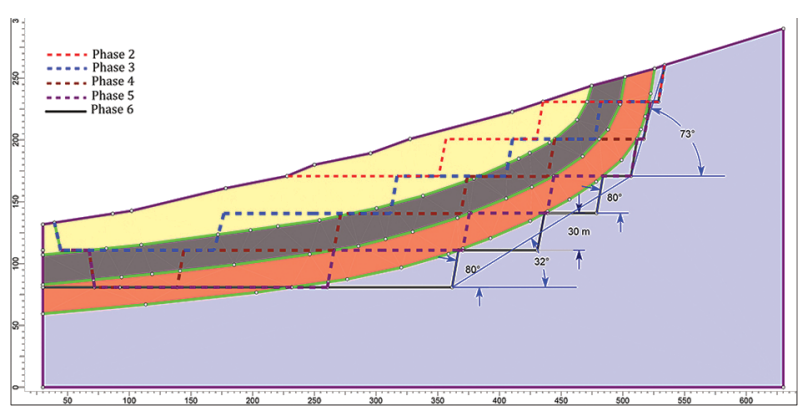

Fig. 6. Excavation sequence slope stability $(S F=4.35)$, which implies that the natural slope is stable in the long-term.

After excavation (Fig. 7), all the safety factors given by different excavation phases are greater than the allowable slope stability threshold $(S F \geq 1.3)$. It implies that the north flank of the mine is stable despite the excavation work that has been done.

Stability analysis under dynamic load. The purpose of this analysis is to verify the stability of the northern flank of the Kef-Essnoun mine under dynamic solicitation. The principle of this analysis is to apply a constant acceleration to the rock mass equivalent to the maximum acceleration felt during a blasting. The calculation results obtained (Fig. 8) are summarized in Table 4.

Based on the results of the numerical modelling of safety factors under dynamic load (Table 4) for different excavation phases, it can be seen that the values are above the accepted

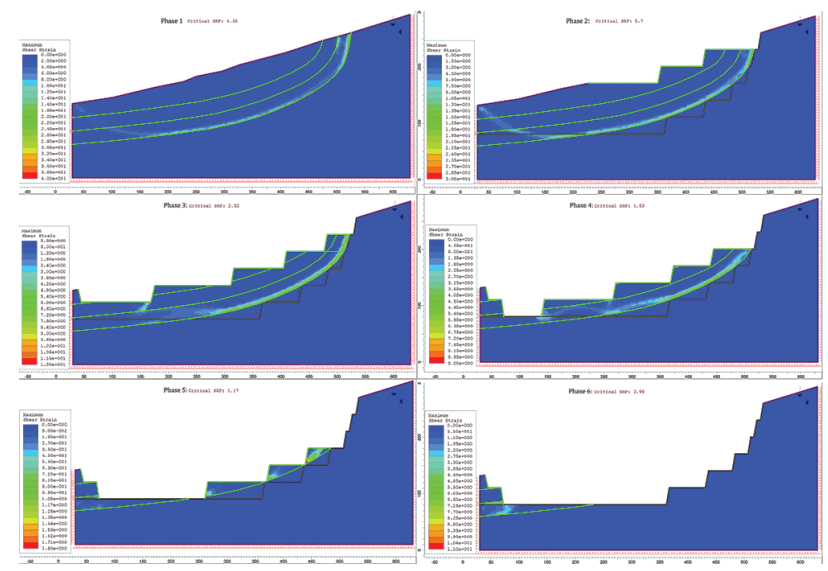

Fig. 7. Maximum shear stress and safety factor under static load

Table 3

Safety factors for different phases under static conditions

\begin{tabular}{|l|c|c|c|c|c|c|}
\hline $\begin{array}{l}\text { Excavation } \\
\text { phases }\end{array}$ & $\begin{array}{c}\text { Phase } \\
1\end{array}$ & $\begin{array}{c}\text { Phase } \\
2\end{array}$ & $\begin{array}{c}\text { Phase } \\
3\end{array}$ & $\begin{array}{c}\text { Phase } \\
4\end{array}$ & $\begin{array}{c}\text { Phase } \\
5\end{array}$ & $\begin{array}{c}\text { Phase } \\
6\end{array}$ \\
\hline Safety factors & 4.35 & 5.70 & 2.52 & 1.53 & 1.37 & 4.10 \\
\hline
\end{tabular}




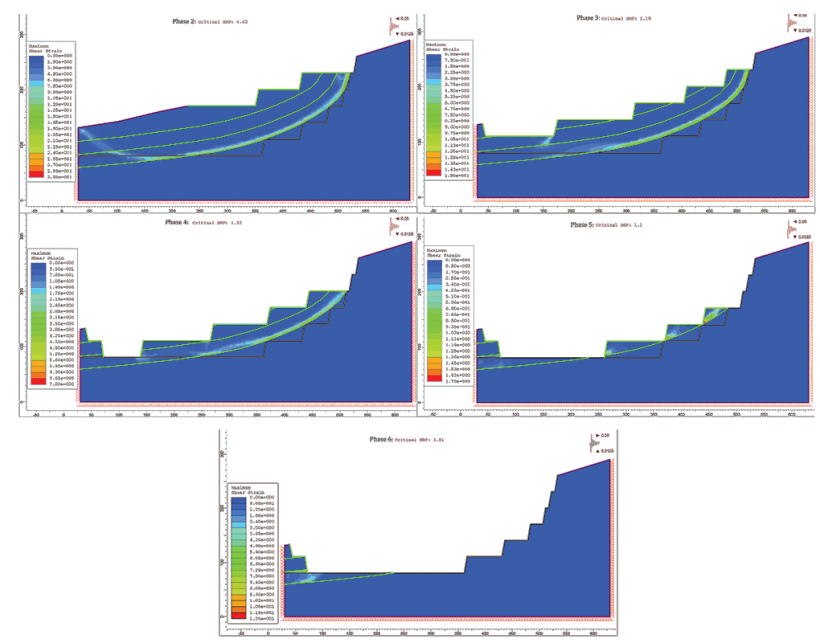

Fig. 8. Maximum shear stress and safety factor under dynamic load

Table 4

Safety factors for different phases under dynamic load condition

\begin{tabular}{|c|c|c|c|c|c|c|}
\hline $\begin{array}{c}\text { Excavation } \\
\text { phases }\end{array}$ & $\begin{array}{c}\text { Phase } \\
1\end{array}$ & $\begin{array}{c}\text { Phase } \\
2\end{array}$ & $\begin{array}{c}\text { Phase } \\
3\end{array}$ & $\begin{array}{c}\text { Phase } \\
4\end{array}$ & $\begin{array}{c}\text { Phase } \\
5\end{array}$ & $\begin{array}{c}\text { Phase } \\
6\end{array}$ \\
\hline Safety factors & - & 4.63 & 2.19 & 1.32 & 1.1 & 3.81 \\
\hline
\end{tabular}

minimum slope stability threshold $(S F \geq 1.1)$ (Fig. 8), which implies that the north flank of the mine remains stable in the long run.

Conclusions. The back analysis of the slip site allowed us to reconstruct the break already observed and to draw maximum lessons on the mode, location and mechanical parameters that triggered this break. These parameters were estimated for a critical state $(S F=1)$, with $120 \mathrm{kPa}$ for the cohesion $(C)$ and $16.47^{\circ}$ for the internal friction angle $(\varphi)$.

The stability analysis carried out on the northern flank of the Kef-Essnoun mine using a rigorous numerical approach (finite difference method) showed that the rupture occurred in the marl layer; which confirmed the observations made in the field.

The parametric study showed us that the flank of the KefEssnoun mine remains unstable even if the height and angle of dip are sufficiently reduced, the safety factors under static and dynamic loads estimated at 1.074 and 0.940 respectively by the simplified Janbu method for steps of $15 \mathrm{~m}$ of height and $75^{\circ}$ of dip.

The slip analysis performed on the north flank of the KefEssnoun mine shows that non-compliance with the art, open pit mining standards and early planning of the mining method can most often lead to critical situations and catastrophic results.

The sinking operation (top down) of the north flank of the Kef-Essnoun mine has ensured greater stability of the entire slope along the exploitation phase.

Acknowledgments. The authors would like to thank the staff of the Mining and Geology Department, University of Bejaia, Algeria and the staff of laboratory (Natural resources and planning, University of Annaba, Algeria).

\section{References.}

1. Fleurisson, J.A. (2012). Slope Design and Implementation in Open Pit Mines: geological and Geomechanical Approach. Procedia Engineering, 46, 27-38. https://doi.org/10.1016/i. proeng.2012.09.442.

2. Ardouz, G., Baba, K., \& Ouadif, L. (2019). Modelling Landslides by the Finite Element Method: Application to an Embankment on a Railway in the Moroccan Rif. In: Hemeda, S., \& Bouassida, M. (Eds). GeoMEast 2018. SUCI, (pp. 133-141). https://doi.org/10.1007/978-3-030-01941-9 11.
3. Saadoun, A., Hafsaoui, A., Khadri, Y., Fredj, M., Boukarm, R., \& Nakache, R. (2019). Study Effect of Geological Parameters of the Slope Stability by Numerical Modelling, Case Limestone Career of Lafarge M'sila, Algeria. IOP Conference Series: Earth and Environmental Science, 221, 012021. https://doi.org/10.1088/1755-1315/221/1/012021.

4. Burman, A., Acharya, S.P., Sahay, R. R., \& Maity, D. (2014). A comparative study of slope stability analysis using traditional limit equilibrium method and finite element method. Asian journal of civil engineering (BHRC), 16(4), 467-492. 5. Boukarm, R., Houam, A., Fredj, M., \& Boucif, R. (2019). Geotechnical risk assessment of rock slope stability using nonlinear strength criterion. Naukovyi Visnyk Natsionalnoho Hirnychoho Universytetu, (4), 48-54. https://doi.org/10.29202/ nvngu/2019-4/4.

6. Soon, M. N., Ismail, A. M., \& Abustan, I. (2014). Back Analysis of Slope Failure Using Finite Element with Point Estimate Method (FEMPEM). Journal of Civil Engineering Research, 4(3A), 31-35. https://doi.org/10.5923/c. jce.201402.04. 7. Jiang, S. H., Huang, J., Yao, C., \& Yang, J. (2017). Quantitative risk assessment of slope failure in 2-D spatially variable soils by limit equilibrium method. Applied Mathematical Modelling, 47, 710-725. https://doi.org/10.1155/2019/6268079.

8. Saadoun, A., Hafsaoui, A., Khadri, Y., \& Fredj, M. (2018). Numerical modelling of slope stability in Chouf Amar limestone quarry (M'sila, Algeria). Naukovyi Visnyk Natsionalnoho Hirnychoho Universytetu , (5), 24-29. https://doi.org/10.29202/ nvngu/2018-5/3.

9. Phoon, K. K. (2017). Role of reliability calculations in geotechnical design. Georisk, 11(1), 4-21. https://doi.org/10.1080 /17499518.2016.1265653.

10. Sakurai, S. (2017). Back analysis in rock engineering, international Society for Rock mechanics (ISRM). London: Taylor \& Francis Group. https://doi.org/10.1201/978131537 5168.

11. Fredj, M., Hafsaoui, A., Boukarm, R., Nakache, R., \& Saadoun, A. (2019). Numerical Modelling of Slope Stability in Open Pit Phosphate Mines, Algeria: A Comparative Study. IOP Conference Series: Earth and Environmental Science, 221, 012020. https://doi.org/10.1088/1755-1315/221/1/012020.

12. Fredj, M., Hafsaoui, A., Khadri, Y., \& Boukarm, R. (2018). Influence of the failure surface choice on the safety factor value during slope stability studies. Naukovyi Visnyk Natsionalnoho Hirnychoho Universytetu, (3), 31-35. https:// doi.org/10.29202/nvngu/2018-3/3.

\section{Вивчення стабільності схилів у кар'єрі на основі ретроспективного аналізу (Алжир)}

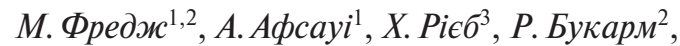

$$
\begin{aligned}
& \text { A. Саaдyн }{ }^{1,2}
\end{aligned}
$$

1 - Лабораторія природничих ресурсів і планування, Університет Баджи Мохтар, м. Аннаба, Алжир, e-mail: mohamed.fredj@univ-bejaia.dz; abderrazak.saadoun@univbejaia.dz

2 - Гірничо-геологічний факультет, Університет Абдеррахмане Mipa, м. Беджая, Алжир, e-mail: riadh.boukarm@ univ-bejaia.dz

3 - Кафедра наук про Землю, Університет Сетіф-1, м. Сетіф, Алжир, e-mail : hadji.rihab@univ-setif.dz

Мета. Проаналізувати зсувне переміщення гірських порід із геолого-технічної точки зору й визначити ймовірні причини, що впливають на це.

Методика. Щоб проаналізувати зсувне переміщення гірських порід із геолого-технічної точки зору й визначити ймовірні причини, що впливають на це, наше дослідження було виконано в наступному хронологічному порядку. По-перше, зворотний зв'язок відновить процес зміщення з геолого-технічної точки зору; аналіз ретроспективний необхідний для підтвердження руйнування 
поверхні. Далі буде проведена перевірка руйнування поверхні за допомогою методу скінченних різниць та використання зменшення міцності на зрушення методом кінцевих різниць (ЗМЗ-КР). Виконано параметричне дослідження впливу геометричних параметрів, щоб побачити вплив останніх на стійкість. Показана ймовірна причина, що безпосередньо вплинула на це.

Результати. У даній роботі розглядається застосування трьох методів: методу граничної рівноваги (МГР), методу скінченних елементів (МСЕ) і методу скінченних різниць (МСР), щоб виконати ретроспективний аналіз і з'ясувати пласт руйнування схилу в кар'єрі.

Наукова новизна. Полягає в тому, що були використані три різних підходи МГР, МСЕ і МСР для ретроспективного аналізу властивостей гірської маси й дослідження механізму руйнування схилу та точність цього методу в області гірничого машинобудування.

Практична значимість. Дане дослідження продемонструвало, що невідповідність рівню техніки, стандартам розробки відкритим способом і ранньому плануванню методу видобутку найчастіше може призвести до критичних ситуацій і катастрофічних результатів. Ретроспективний аналіз місця зсуву дозволив нам відновити обвалення, що вже спостерігалося, і засвоїти максимум уроків щодо режиму, місця розташування й механічних параметрів, що викликали це обвалення.

Ключові слова: обвал, метод граничної рівноваги, метод кінцевих різниць, метод кінцевих елементів, кар'єр, стійкість схилу

\section{Изучение стабильности склонов в карьере на основе ретроспективного анализа (Алжир)}

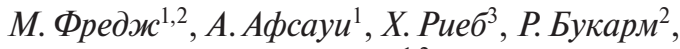

$$
\begin{aligned}
& \text { A. Саaдyн }{ }^{1,2}
\end{aligned}
$$

1 - Лаборатория природных ресурсов и планирования, Университет Баджи Мохтар, г. Аннаба, Алжир, е-mail: mohamed.fredj@univ-bejaia.dz; abderrazak.saadoun@univbejaia.dz

2 - Горно-геологический факультет, Университет Абдеррахмане Мира, г. Беджая, Алжир, e-mail: riadh.boukarm@ univ-bejaia.dz

3 - Кафедра наук о Земле, Университет Сетиф-1, г. Сетиф, Алжир, e-mail : hadji.rihab@univ-setif.dz
Цель. Проанализировать оползневое перемещение горных пород с геолого-технической точки зрения и определить вероятные причины, которые влияют на это.

Методика. Чтобы проанализировать оползневое перемещение горных пород с геолого-технической точки зрения и определить вероятные причины, которые влияют на это, наше исследование было выполнено в следующем хронологическом порядке. Во-первых, обратная связь восстановит процесс смещения с геолого-технической точки зрения; анализ ретроспективный необходим для подтверждения разрушения поверхности. Далее будет произведена проверка разрушения поверхности с помощью метода конечных разностей и использования уменьшения прочности на сдвиг методом конечных разностей (УПС-КР). Выполнено параметрическое исследование влияния геометрических параметров, чтобы увидеть влияние последних на устойчивость. Показана вероятная причина, которая непосредственно повлияла на это.

Результаты. В данной работе рассматривается применение трех методов: метода предельного равновесия (МПР), метода конечных элементов (МКЭ) и метода конечных разностей (МКР), чтобы выполнить ретроспективный анализ и выяснить пласт разрушения склона в карьере.

Научная новизна. Состоит в том, что были использованы три разных подхода МПР, МКЭ и МКР для ретроспективного анализа свойств горной массы и исследования механизма разрушения склона и точность этого метода в области горного машиностроения.

Практическая значимость. Данное исследование продемонстрировало, что несоответствие уровню техники, стандартам разработки открытым способом и раннему планированию метода добычи чаще всего может привести к критическим ситуациям и катастрофическим результатам. Ретроспективный анализ места смещения позволил нам восстановить обрушение, которое уже наблюдалось, и извлечь максимум уроков касательно режима, местоположения и механических параметров, которые вызвали это обрушение.

Ключевые слова: обвал, метод предельного равновесия, метод конечных разностей, метод конечных элементов, карьер, устойчивость склона

Recommended for publication by Aissa Benselhoub. The manuscript was submitted 05.05.19. 